\title{
Response of a mixed Philippine seagrass meadow to experimental burial
}

\author{
Carlos M. Duarte ${ }^{1, *}$, Jorge Terrados ${ }^{1}$, Nona S. R. Agawin $^{1}$, Miguel D. Fortes ${ }^{2}$, \\ Stefien Bach ${ }^{3}$, W. Judson Kenworthy ${ }^{4}$ \\ ${ }^{1}$ Centro de Estudios Avanzados de Blanes, CSIC, Cami de Santa Bárbara s/n, E-17300 Blanes, Girona, Spain \\ ${ }^{2}$ Marine Sciences Institute, College of Science, University of The Philippines, Diliman, 1101 Quezon City, The Philippines \\ ${ }^{3}$ Freshwater Biological Laboratory, University of Copenhagen, Helsingorsgade 51, DK-3400 Hillerød, Denmark \\ ${ }^{4}$ SE Fisheries Laboratory, National Marine Fisheries Center, NOAA, 11 Pivers Road, Beaufort, North Carolina, USA
}

\begin{abstract}
The effect of burial due to sudden sediment loading was examined in a mixed Philippine seagrass meadow through the experimental deployment of sediment $(0,2,4,8$, and $16 \mathrm{~cm}$ deposited over the experimental plots). The responses in shoot density, vertical growth, and branching of the species present were assessed 2, 4, and 10 mo following disturbance. Shoot density responses were strongly species-specific. The large Enhalus acoroides maintained shoot density at all burial treatments, and only showed evidence of decline by the end of the experiment. Thalassia hemprichii and, to a lesser extent, Cymodocea rotundata showed a sharp decline in shoot density even at moderate burial treatments, from which they failed to recover. The accompanying species (Halodule uninervis, Syringodium isoetifolium, and Cymodocea serrulata) showed an initial decline in shoot density followed by recovery. The small Halophla ovalis showed an opportunistic growth in plots receiving intermediate (buried by 4 and $8 \mathrm{~cm}$ sediment) disturbance, reaching shoot densities well in excess of those on control plots. The results suggest a pattern of species loss following disturbance by sediment burial corresponding to the sequence, $T$ hemprichii $\rightarrow(C$. rotundata, S. isoetifolium, $H$. uninervis $) \rightarrow C$. serrulata $\rightarrow E$. acoroides. Vertical growth increased significantly for all species with differentiated vertical shoots, except $C$ serrulata. The examination of the time course of vertical growth imprinted on the shoots of the dominant species, $T$ hemprichii, revealed a rapid response to burial through increased internodal length, which was maintained over 8 mo following the disturbance. The resulting cumulative vertical growth along the experiment was linearly correlated with the degree of burial imposed on the plants. Branching of vertical shoots also increased significantly $(73$ to $96 \%$, depending on the species) with burial. Experimental burial induced changes in shoot age distribution of some of the species, involving rearrangements, through selective mortality or recruitment, of the contribution of young shoots to the populations. The results obtained show major differences in species response to small-scale disturbance, closely linked to predictions derived from consideration of species growth rate and size, and provide evidence of the importance of small-scale disturbance in the maintenance of multispecific seagrass meadows.
\end{abstract}

KEY WORDS: Seagrass $\cdot$ SE Asia $\cdot$ Disturbance $\cdot$ Sediment burial

\section{INTRODUCTION}

Physical disturbance is considered one of the main factors that determines the spatial structure and species diversity of seagrass meadows (den Hartog 1971, Shepherd 1981, Fonseca \& Kenworthy 1987, Clarke \& Kirkman 1989). Seagrasses growing in tropical coastal waters often experience disturbances induced by trop-

•E-mail: duarte@azathoth.ceab.es ical storms that are believed to be major factors in the dynamics of these seagrass meadows (Birch \& Birch 1984, Eleuterius 1987, Williams 1988, Clarke \& Kirkman 1989, Poiner et al. 1989, Tilmant et al. 1994, Preen et al. 1995). Besides the loss of plant biomass, the turbulence generated by these storms causes large-scale sediment redistribution, which buries adjacent meadows (Marbá et al. 1993, Preen et al. 1995). The effects of tropical storms on sediment redistribution may be exacerbated by the discharge of sediments in coastal 
areas experiencing significant land erosion (Preen et al. 1995). In addition to land erosion, episodic largescale sediment deposition in the coastal zone also results from transport of sediments produced during landslides and residues from mining activities during the heavy rainfalls that accompany tropical storms. In addition to large-scale disturbance, the activity of burrowing organisms (e.g. burrowing shrimps) can also lead to important sediment redistribution at the local scale (Suchanek 1983, Ward 1989, Ziebis et al. 1996).

The response of seagrass meadows to the disturbance generated by sediment redistribution has been described only through qualitative observations or from historical reconstructions. The accounts available indicate that these disturbances cause substantial mortality, followed by an apparent enhancement of the growth of the few surviving plants, and a differential capacity for recovery among the different species (Birch \& Birch 1984, Eleuterius 1987, Clarke \& Kirkman 1989, Poiner et al. 1989, Preen et al. 1995),

Mixed seagrass communities in SE Asia typically comprise up to 13 species, ranging broadly in size from small IJálophila sp. to the large Enhalus acoroides (Brouns 1987b, Poiner et al. 1989, Fortes 1994). Comparative analysis of the size, architecture, and growth rate of these species (e.g. Brouns 1987 a, Vermaat et al. 1997) has permitted the development of hypotheses on the relative capacity of each species to survive and recover from disturbance. Some of the species, such as E. acoroides, are sufficiently large as to maintain abundant photosynthetic surface even after large-scale burial. Species of intermediate size, such as Thalassia hemprichii, can be greatly shaded and buried by sediment redistribution. However, many of these species have short shoots that grow vertically allowing some compensatory growth response after burial (e.g. Marbá et al. 1993, 1994, Marbá \& Duarte 1994, 1995), although the importance of vertical growth varies considerably among species (cf. Vermaat et al. 1995). Lastly, relatively smaller species (e.g. Halophila spp., Halodule spp., and Syringodium spp.) can be decimated by even a modest burial, but grow fast (Duarte 1991) and may be able to quickly recover following disturbance (Eleuterius 1987. Fonseca et al. 1987. Williams 1987, 1990, Poiner et al. 1989).

These considerations lead us to hypothesise that the mortality induced by burial should increase with decreasing seagrass size, whereas the capacity to recover from this catastrophic mortality should also increase with decreasing seagrass size. As a consequence, seagrass species with intermediate sizes are expected to experience substantial mortality and also require comparatively long times to recover, being, therefore, the species most heavily influenced by the disturbance associated with sediment burial. These predictions can be used, if experimentally validated, to forecast the effects of disturbances, both natural and man-made, on seagrass ecosystems, or to infer the frequency or extent of disturbance from the species composition of meadows.

Here, we provide a first test of the response of a SE Asian seagrass meadow to small-scale experimental burial, with an emphasis in testing the predictions on the differential response of species with contrasting size and growth capacity. We do so in a mixed Philippine seagrass meadow (Silaqui Island, Cape Bolinao cf. Vermaat et al, 1995). The meadow selected for the experiment contains 7 species encompassing the full range of sizes present in the seagrass flora (cf. Duarte 1991) allowing for the comparative examination of their response to experimental burial. Further, this meadow is a good representative of the multispecific meadows that characterise SE Asia seagrass flora (Brouns 1987b, Poiner et al. 1989).

\section{MATERIAL AND METHODS}

The experimental burial was performed in a seagrass meadow located in the reef flat between Silaqui and Santiago islands $\left(16^{\circ} 26.35^{\prime} \mathrm{N}, 119^{\circ} 55.46^{\prime} \mathrm{E}\right)$, Bolinao, Pangasinan, The Philippines (cf. Fig. 1 in Vermat et al. 1995). The meadow is dominated by Thalassia hemprichii (Ehrenberg) Ascherson, with a significant contribution to biomass and production of Enhalus acoroides (L.f.) Royle, and Cymodocea rotundata Ehrenberg \& Hemprich ex Ascherson. Other seagrass species present with a smaller share of community biomass and production are: Cymodocea serrulata ( $R$. Brown) Ascherson \& Magnus, Halodule uninervis (Forsskal) Ascherson, Syringodium isoetifolium (Ascherson) Dandy, and Halophila ovalis (R. Brown) Hooker f. (Vermaat et al. 1995). All of the species present in the meadow may be found within a $0.25 \mathrm{~m}^{2}$ plot, although the density of some of the species shows considerable patchiness.

Each experimental unit was circular in shape and had a surface area of $0.5 \mathrm{~m}^{2}$. The experimental units were delimited by a galvanised iron sheet frame anchored by 4 iron pegs. The frames penetrated $2 \mathrm{~cm}$ into the sediment and extended at variable heights $(2,4,8$, and $16 \mathrm{~cm}$ ) over the sediment, depending on the burial treatments they received. The experiment followed a complete randomised block design with 3 random blocks separated 10 to $15 \mathrm{~m}$ from each other, and 5 burial levels [0 (background siltation rate), 2, 4, 8 and $16 \mathrm{~cm}$ above the sediment surface]. Hence, the total number of frames set up was 45 ( 5 treatments $\times 3$ blocks $\times 3$ replicates per block). The frames of the 0 -burial experimental units extended $2 \mathrm{~cm}$ above the sediments to 
control for the effect of the frames. On May 13, 1995, the density of seagrass shoots in each of the frames was estimated by counting all of the Enhalus acoroides shoots present, and the number of shoots of other species in at least ten $10 \times 10 \mathrm{~cm}$ cells within a $50 \times 50 \mathrm{~cm}$ quadrat placed inside each experimental unit. The rhizomes connecting shoots inside experimental plots with those outside were not severed to avoid artifacts, such as an increased mortality and reduced growth due to damage to the rhizomes (Terrados unpubl. results), which are not damaged in a similar way under natural burial. On 14 May, 1995, burial was effected by filling the frames with sediment up to the brim. The experimental sediment was a 2:1 mixture of sand and mud collected at a nearby beach and a river mouth, respectively. This mixture was used to mimic the likely type of sediment that would be delivered to the seagrass meadow by a major disturbance (e.g. tropical storm, typhoon, monsoonal flood), which causes both flooding of rivers and sediment resuspension.

Seagrass response to burial was assessed by harvesting one experimental unit for each treatment per block in July and September 1995, and March 1996. Natural processes, predominantly sediment reworking by burrowing shrimps and resuspension, altered the sediment levels at the experimental units, tending to homogenise sediment levels with time. We made no effort to maintain the initial experimental sediment levels, since we intended to mimic the effect of a disturbance event, not that of sustained burial.

We assessed the effect of burial on seagrasses in different ways. We followed the changes in shoot density of the different seagrass species with time, as well as the age distribution of the vertical shoots (only for the first harvesting period). Shoot density was estimated, following the procedure outlined above, at each of the 3 harvest periods, with the exception that whenever the treatments had caused large mortality, all of the shoots present inside the frames were counted to estimate shoot density. The age distribution of the shoots was established by determining the age, as the sum of the number of leaf scars and standing leaves (Duarte et al. 1994), of all shoots present in the plots harvested 2 mo following the application of experimental burial. Responses in the vertical growth of the species, the most prominent response of seagrasses to burial (Marbá \& Duarte 1994), were assessed by measuring the length of the vertical rhizome internodes produced by the plants after the experimental burial (Duarte et al. 1994). To establish this, we harvested a sample of the plants present in each of the quadrats either by hand or using a stainless steel corer of $20 \mathrm{~cm}$ in diameter $(\mathrm{n}=10)$. The length of the leaf sheath, which has also been shown to increase in response to burial (Marbá \& Duarte 1994), was also measured in the shoots harvested. We also monitored responses in other traits, such as the size (one-sided surface, $\mathrm{cm}^{2}$ ) and specific weight ( $\mathrm{g}$ dry weight $\mathrm{cm}^{-2}$ ) of the leaves in each shoot, and the number and type (horizontal, vertical) of branches produced on the leaf shoots since the burial treatment was applied.

At the end of the experiment (i.e. March 1996) we also measured the sequence of internodal length along the life span of the leaf shoots of Thalassia hemprichii. the longest-living seagrass with vertical shoots present. These measurements, performed under a dissecting microscope as described in Marbá et al. (1993), provided a finer-resolution 11 plastochrone interval (PI) = 9.4 di Vermaat et al. 1995, N. S. R. Agawin, J. Uri \& M. D. Fortes unpubl. data] of the time course of vertical growth in response to burial. The sequence of internodal lengths was examined for all of the harvested $T$. hemprichii shoots older than 50 leaf PIs (about $1.8 \mathrm{yr}$ ), which comprised between 3 and 9 shoots per treatment. The number of shoots of the other, shorter-lived seagrass species that survived throughout the experiment was not sufficient to reliably allow comparison of the internodal sequences between treatments. The digitised internodal sequences were first smoothed, using a running average of 5 internodes (i.e. about $55 \mathrm{~d}$ ), to remove short-term variability (Duarte et al. 1994), and the smoothed sequences were subsequently combined to derive the average length of each internode for each of the treatments. The absolute time encompassed by the time series of vertical internodal length is only approximate, since we did not test whether the duration of a plastochrone interval changes with burial. The cumulative response in vertical growth of the buried plants was further assessed from the excess vertical growth over the control plants (i.e. the difference between the sum of internodal lengths for the treatment and control T. hemprichil shoots).

The effect of burial on leaf shoot density was tested using ANCOVA, with burial treatment and harvest time as independent variables, and the density in control plots at the time of harvest as a covariate to control for patchiness and seasonality in shoot density. Differences in shoot age distribution between treatments were tested for using the non-parametric KolmogorovSmirnov test. The effect of burial on the vertical growth of the different seagrass species (expressed as the mean length of the rhizome internodes produced by the vertical shoots during the experiment) was assessed 2 mo after the burial of the plants, using ANOVA. Prior to the statistical analysis the data were tested for normality and homoscedasticity. The data were transformed to fulfill the assumptions of ANOVA. Whenever transformation did not meet the parametric assumptions, a Kruskal-Wallis non-parametric ANOVA instead of the parametric analysis was used. 


\section{RESULTS}

Examination of the time course of shoot density on control plots revealed substantial temporal variations in some of the species present (Figs, 1 \& 2), which may reflect seasonality as observed in the past (N. S. R. Agawin, J. Uri \& M. D. Fortes unpubl. results). These temporal differences were particularly evident for Syringodium isoetifolium. Halodule uninervis, and Cymodocea serrulata, and there was no evidence of such seasonality for $C$. rotundata. In contrast, Enhalus acoroides showed a trend towards increasing shoot density in control plots over the initial 4 mo of the experiment (Fig. 1). The spatial distribution of all the species was patchy and resulted in great variance in shoot density estimates and a limited power to detect signuficant responses to buriaì (Fig. 2), implyiny that subtle changes may have been undetected by our analysis. Patchiness was particularly
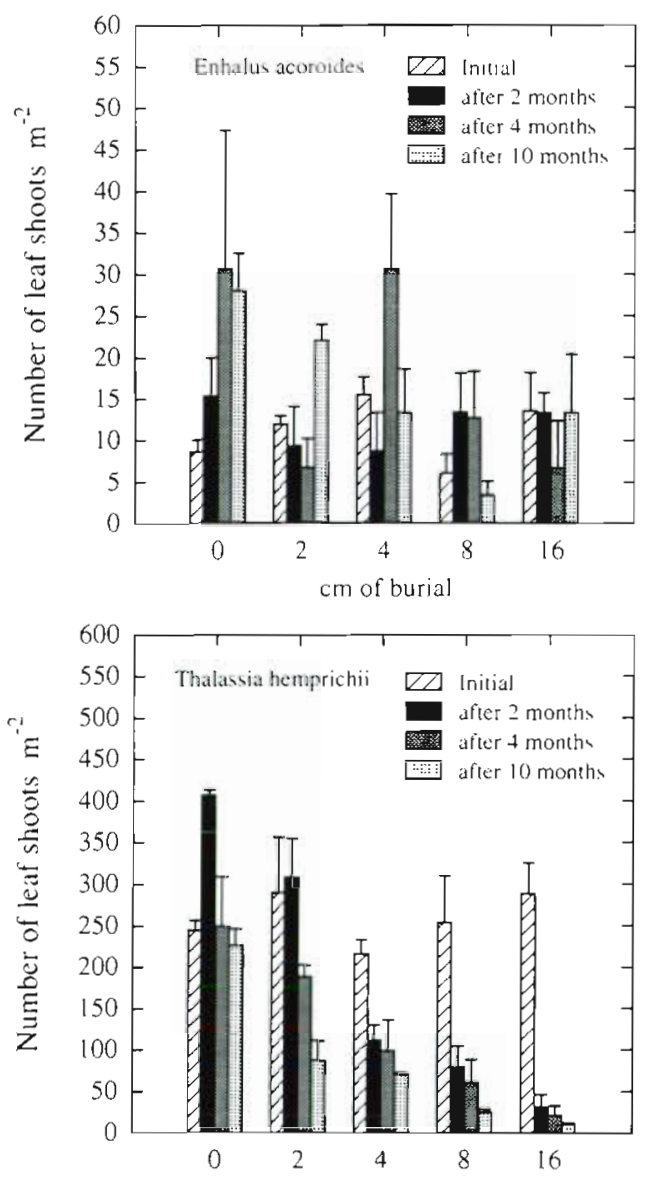

Fig. 1 Enhalus acoroides and Thalassia hemprichii. Shoot density in plots subject to different burial treatment in the different periods examined. Error bars indicate \pm SE of the mean
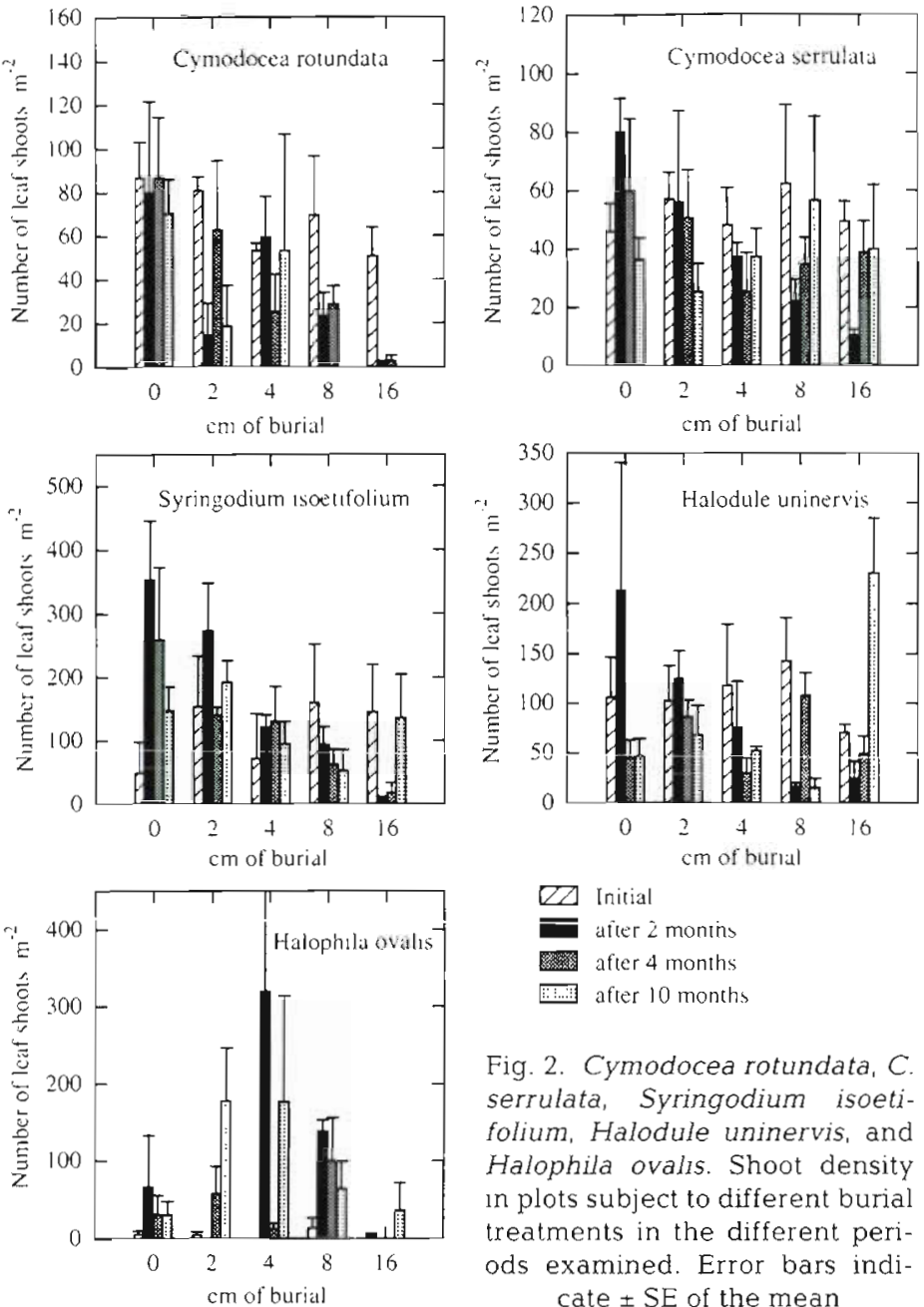

$\square D$ Initial

Euter 2 monins

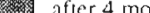

E.:.: after 10 months

Fig. 2. Cymodocea rotundata, C. serrulata, Syringodium isoetifolium, Halodule uninervis, and Halophila ovalis. Shoot density in plots subject to different burial treatments in the different periods examined. Error bars indicate $\pm \mathrm{SE}$ of the mean

important for the small Halophila ovalis, reflected in a greater variability in initial density between plots (coefficient of variation $=167 \%$ ) compared to that of the other species (coefficient of variation $<100 \%$ ).

The changes in shoot density in response to burial were species-specific. The effect of burial on Enhalus acoroides varied along the experiment, with the plants showing a significant reduction in shoot density only by the end of the experiment (ANOVA, only data at the final harvest, $F=3.6148, p=0.0296$; Fig. 1). In contrast, the dominant species, Thalassia hemprichii, showed a significant decline in shoot density with increasing burial (Fig. 1, Table 1). Most of the small species showed an initial decline in shoot density at high burial treatments, which was opposed in some of them (e.g. Halodule uninervis, Syringodium isoetifolium, Cymodocea serrulata) by a tendency to recover with increasing time since the disturbance (Fig. 2). C. rotundata showed no such capacity to recover over the time span of the experiment, with the species being lost from the high burial treatments (Fig 2). The small 
Table 1. Summary of the test of the response of shoot density (ANCOVA or Kruskal-Wallis test), and the mean internode length (MIL) of the vertical rhizomes produced over the first 2 mo of the experiment (ANOVA or Kruskal-Wallis test) by the different species present to the burial treatment applied, and the interaction between burial treatment and harvest time. The density in control plots was used as a covariate to control for patchiness and seasonality in the analysis of shoot density. Results are summarised by the $F$-ratio or the Kruskal-Wallis statistic, $H$, and the associated probability value

\begin{tabular}{|c|c|c|c|c|c|c|c|}
\hline \multirow[t]{2}{*}{ Species } & \multirow[t]{2}{*}{ Response } & \multicolumn{2}{|c|}{ Burial } & \multicolumn{2}{|c|}{ Burial $\times$ Time } & \multicolumn{2}{|c|}{ Initial density (Covariate) } \\
\hline & & $F$-ratio & $\mathrm{p}$ & $F$-ratio & $p$ & $F$-ratio & $\mathrm{p}$ \\
\hline Enhalus acoroides & $\begin{array}{l}\text { Density } \\
\text { MlL }^{a}\end{array}$ & 1.283 & 0.304 & 2.946 & 0.028 & 0.494 & 0.489 \\
\hline Thalassia hemprichu & $\begin{array}{l}\text { Density }{ }^{b} \\
\text { MIL }\end{array}$ & $\begin{array}{r}27.549 \\
9.393\end{array}$ & $\begin{array}{l}<0.001 \\
<0.001\end{array}$ & 1.330 & 0.284 & 0.562 & 0.461 \\
\hline Cymodocea rotundata & $\begin{array}{l}\text { Density } \\
\text { MIL }^{d}\end{array}$ & $\begin{array}{r}6.049 \\
23.677\end{array}$ & $\begin{array}{r}0.109 \\
<0.001\end{array}$ & & & & \\
\hline Cymodocea serrulata & $\begin{array}{l}\text { Density } \\
\text { MIL }^{\ddagger}\end{array}$ & $\begin{array}{l}0.416 \\
1.495\end{array}$ & $\begin{array}{l}0.743 \\
0.683\end{array}$ & 1.000 & 0.449 & 0.044 & 0.836 \\
\hline Syringodium isoetifolium & $\begin{array}{l}\text { Density } \\
\text { MIL }^{d}\end{array}$ & $\begin{array}{r}8.216 \\
12.891\end{array}$ & $\begin{array}{r}<0.001 \\
0.005\end{array}$ & 1.832 & 0.137 & 0.651 & 0.428 \\
\hline Halodule uninervis & $\begin{array}{l}\text { Density } \\
\text { MIL }^{d}\end{array}$ & $\begin{array}{r}3.587 \\
19.877\end{array}$ & $\begin{array}{l}0.029 \\
0.005\end{array}$ & 8.004 & $<0.001$ & 3.305 & 0.082 \\
\hline Halophila ovalis & $\begin{array}{l}\text { Density } \\
\text { MIL }^{d}\end{array}$ & 10.999 & 0.012 & & & & \\
\hline
\end{tabular}

Halophila ovalis showed a pattern different from those of any other species, involving an early increase in abundance at intermediate burial levels (Fig. 2). These changes in shoot density resulted in significant responses of shoot density to burial for $T$. hemprichii, $S$. isoetifolium, $H$. uninervis and $H$. ovalis, with $E$. acoroides and $H$. uninervis also showing a significant interaction between burial and time (Table 1). However, the interactions between burial and time resulted from different responses for these species, with $E$. acoroides becoming increasingly depleted with time (Fig. 1), whereas $H$. uninervis showed a tendency towards recovering with time (Fig. 2).

Burial had effects on the age distribution of the shoots shortly after the initiation of the experiments. The age distribution of Thalassia hemprichii shoots differed between control and disturbed plots (Kolmogorov-Smirnov test, $p<0.03$ ), with a tendency towards a selective loss of young ( $<1$ yr) shoots involving a somewhat reduced recruitment (Fig. 3). The age distribution of

Fig. 3. Thalassia hemprichii, Cymodocea rotundata, $C$. serrulata, Halodule uninervis, and Syringodium isoetifolium. Age distribution of the vertical shoots of the species present 2 mo following experimental burial. Age classes represent approximate year classes, with the first age class grouping the shoots produced after the initiation of the experiment
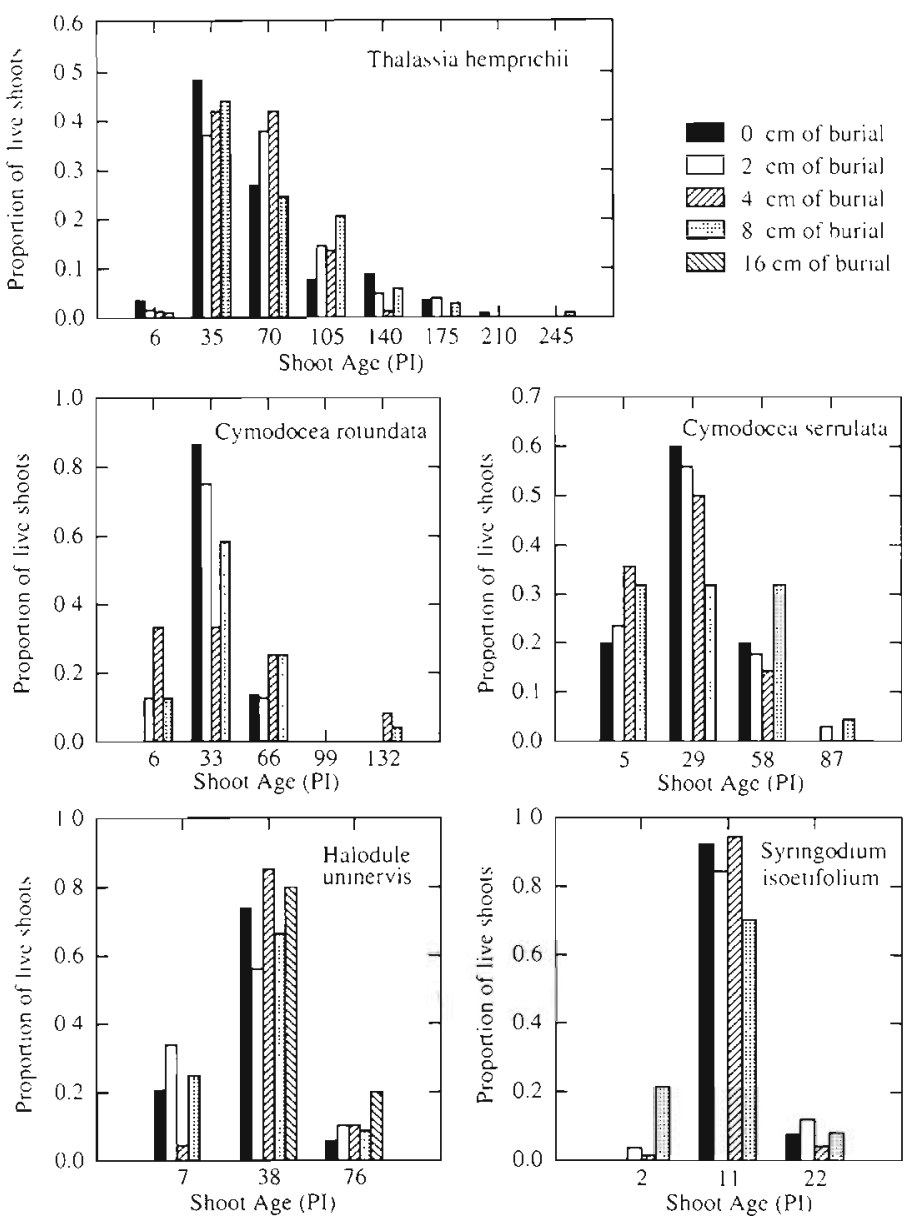

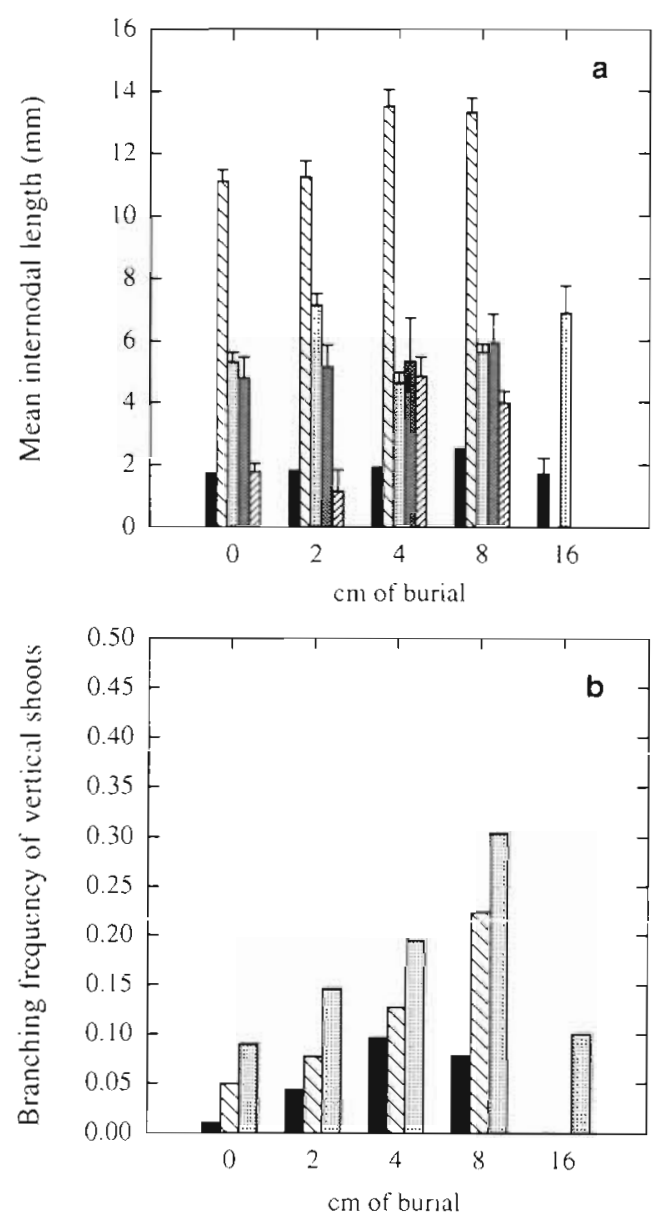

\begin{abstract}
- Thalassia hemprichii
Cymodocea serrulara $\square$ Syringodium ısoecifolium Halodule uninervis
\end{abstract}

Fig. 4. Thalassia hemprichii, Syringodium isoetifolium, Halodule uninervis, Cymodocea serrulata, and C. rotundata. (a) Mean length (error bars, $\pm S E$ ) of the vertical rhizome internodes produced during the first 2 mo of the experiment, and (b) frequency of shoots branching over the same period for the different species present

Syringodium isoetifolium and Halodule uninervis shoots also changed significantly with burial (Kolmogorov-Smirnov test, $\mathrm{p}<0.03$ ), involving a relative increase in recruitment of young ( $<1 \mathrm{yr}$ ) shoots and a more complex age-dependent response to burial, respectively (Fig. 3). No significant difference in age distribution between control and disturbed plots was observed for either of the Cymodocea species.

The length of the vertical internodes produced during the experiments increased significantly with the extent of burial in some of the species supporting vertical growth (i.e. all except Halophila ovalis and Enhalus acoroides, cf. Duarte et al. 1994, Vermaat et al. 1995) (Table 1). The increase was greatest for Cymodocea rotundata, where internodes grew about 3-fold longer in response to 4 or $8 \mathrm{~cm}$ of burial (Fig. 4 ), while C. serrulata showed no response to burial. Thalassia hemprichii, Syringodium isoetifolium, and Halodule uninervis showed significant, but modest increments in the length of their vertical internodes with maxima at 8,4 and 8 , and $2 \mathrm{~cm}$ of burial, respectively (Table 1 , Fig. 4). The fact that maximal internodal lengths are reached at different burial treatments for different species is likely associated to the stress imposed by high sediment burial on some species (as evidenced from sharp mortality), which may have prevented further growth responses in internodal length at higher burial levels. Examination of shoot size (one-sided surface, $\mathrm{cm}^{2}$ ), sheath length and leaf specific weight $(\mathrm{g}$ dry weight $\mathrm{cm}^{-2}$ ) showed no apparent response to burial throughout the experiment. The branching frequency of the vertical shoots of all species with enough survivors to allow reliable estimation of this parameter increased greatly (3- to 8-folud) in response to burial (Fig. 4). Branching produced both horizontal and vertical rhizomes, although the latter were produced more frequently $(73 \%$ for $T$. hemprichii, $81 \%$ for S. isoetifolium and $36 \%$ for $U$. unincrisis).

The increased shoot vertical growth evident after 2 mo was sustained for longer terms by some of the species. Thalassia hemprichii maintained higher vertical growth in response to burial over $4 \mathrm{mo}$, although the internodes produced just before the final harvest (i.e. 10 mo after the burial was applied) did not differ significantly among treatments (Fig. 5). Examination of the time series of the average internodal length produced by $T$ hemprichii shoots showed a clear increase in internodal length in response to burial (Fig. 5). The average length of the internodes produced between 10 and 35 PIs (i.e. about 100 and 350 d) before the end of the experiment increased with increasing burial (Fig. 5), indicating that the growth response to the disturbance extended over about $8 \mathrm{mo}$. The response is already evident in internodes present at the time burial was applied (Fig. 5), consistent with the observations that seagrass internodes continue to elongate for some time after they are initially formed (Marbá \& Duarte 1994). The differences among treatments in the average length of the internodes produced 8 mo after the initiation of the experiment (about 15 PIs before final harvest) were, however, much smaller or nonexistent (Fig. 5). Integration of the vertical growth the $T$. hemprichii shoots produced over the length of the experiment revealed growth to be strongly correlated with the burial treatment applied. The cumulative vertical growth in response to burial was closely correlated $(r=0.98, p<0.002)$, albeit not equivalent, to the depth to which the plants were buried, with cumulative vertical growth representing, on average, a third of the thickness of the sediments distributed over the plants. 


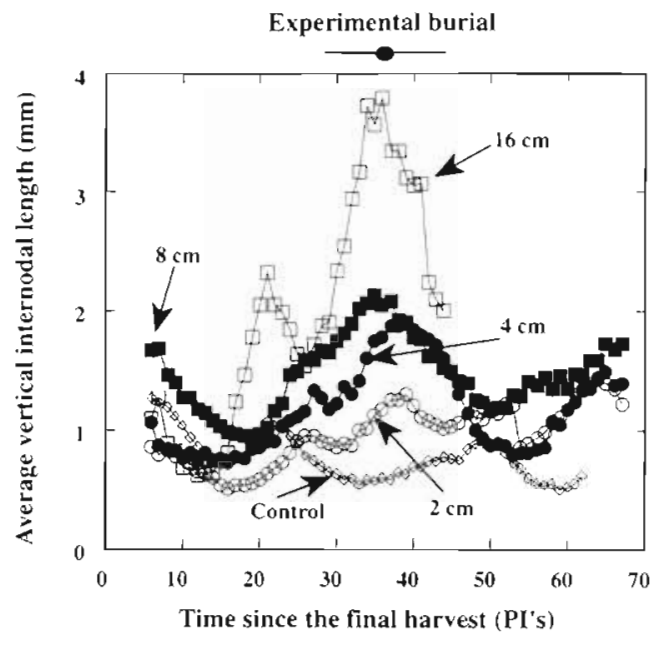

Fig. 5. Thalassia hemprichii. Time sequence of the average length of the vertical internodes of shoots subject to different sediment burial. The abscissa represents the time, in plastochrone intervals, when the internodes were formed on the shoot before the final harvest (March 1996). The full circle over the plot indicates the time at which experimental burial was applied, estimated from the mean chronological duration of a plastochrone interval observed over 3 consecutive years of marking of $T$ hemprichii leaves in this site (N. S. R. Agawin, J. Uri \& M. D. Fortes unpubl data). The bars extend to the upper and lower $95 \%$ confidence limits of this estimate

\section{DISCUSSION}

The results obtained clearly demonstrate that the response of a mixed community to the disturbance induced by sudden burial is species-specific. The net mortality differed greatly among species, with the largest species, Enhalus acoroides, remaining virtually unaffected by even the greatest burials. There was, however, some response of this species by the end of the experiment, suggesting that the duration of the experiment may have been insufficient to fully establish the response of this slow-growing species. In contrast, the dominant species, Thalassia hemprichii, declined quickly in response to burial. Most of the small species also showed an initial decline, but were able to recover within the time span of the experiment (about $1 \mathrm{yr}$ ). The results of the experiment, therefore, suggest a pattern of species loss upon perturbation following the sequence (from the first species to be lost to the most resistant species): T. hemprichii $\rightarrow$ (Cymodocea rotundata, Syringodium isoetifolium and Halodule uninervis) $\rightarrow$ C. serrulata $\rightarrow E$. acoroides. Burial under $>4 \mathrm{~cm}$ of sediment must undoubtedly have caused the mortality of the small Halophila ovalis, which would have been totally buried. Yet, our results showed no evidence of any detrimental long-term effects of burial on $H$. ovalis. Indeed, $H$. ovalis has been shown to fully recover from the disturbance induced by dugong feeding in less than 2 mo (Supanwanid 1996). We conclude that the time scale we used to observe responses (i.e. 2 mo) was too long to elucidate the dynamics of the fast-growing $H$. ovalis, which produces a new leaf pair and rhizome internode every $4 \mathrm{~d}$ (Vermat et al. 1995). The experimental time scale represented a compromise between the relatively long studies needed to observe the full responses of slowgrowing (and slow-reacting) species, such as $E$. acoroides, and shorter studies more appropriate for fast-growing species. For the latter species our experiment allowed not only for the demonstration of response to disturbance, but also for the dynamics of early recovery. At any rate, the results on vertical seagrass growth presented provide evidence that the experimental duration was sufficient to capture the entire response to burial for this important trait.

Mortality of Thalassia hemprichii created large gaps in the canopy, which increased in size with increasing burial. These gaps may explain the fact that some of the small, fast-growing species, notably Halophila ovalis and Halodule uninervis, had reached densities in the high-burial treatment well above (4- to 5-fold greater) those in the controls by the end of the experiment (Fig. 2). This response also suggests that interspecific competition might be important in shaping the mixed community examined. Hence, the loss of the dominant species triggers, at the small-scale of the disturbance tested, a response from the smaller ones, whose populations were presumably suppressed by the dominant species. The nature of the limiting resource affecting these interspecific interactions are, however, unclear, and may involve light, sediment space (Turner 1985, Turner \& Lucas 1985, McConnaughay \& Bazzaz 1991), or nutrients, since the meadow examined is nutrient-limited (Agawin et al. 1996). Longer disturbance experiments are needed to allow a description of the succession of plants towards a new dynamic equilibirum following disturbance (cf. Williams 1990).

The changes in community structure in response to the experimental disturbance followed a pattern similar to those observed after natural or other experimental disturbances. Multispecific seagrass meadows have responded to disturbance with an enhanced growth of fast-growing species (den Hartog 1971, Birch \& Birch 1984, Brouns 1987a, Williams 1987, 1990, Clarke \& Kirkman 1989, Fourqurean et al. 1995), at the expense of the gaps opened by the mortality of the dominant species (Kirkman \& Walker 1989). In a Caribbean multispecific seagrass meadow, the leaf shoot density of Syringodium filiforme doubled within 9 mo after the removal of the leaf canopy of the dominant Thalassia testudinum (Williams 1987). This initial response was 
followed by a decline in $S$. filiforme shoot density as $T$. testudinum recolonized (Williams 1990), Long-term manipulation of nutrient availability in a Caribbean seagrass meadow altered species composition, where faster-growing species (Halodule wrightii) displaced slower-growing $T$. testudinum (Fourqurean et al. 1995). Our results show that some of the species (Cymodocea serrulata, Halophila ovalis, and Halodule uninervis) are able to recover within 4 mo after substantial perturbation. Similar dynamics are also observed as a result of small-scale disturbances. Burrowing shrimps mobilise large volumes of sediment within tropical seagrass meadows (Suchanek 1983, Ward 1989). These shrimps build mounds, which occur at a density of about $3 \mathrm{~m}^{-2}$ in the meadow examined (C. M. Duarte, J. Terrados \& M. D. Fortes unpubl. results), which turnover at a relatively fast rate. These mounts bury the adjacent seagrasses under up to 20 or $30 \mathrm{~cm}$ of sediment, and are rapidly colonised by $H$. ovalis. Halophila species are usually reported as the first colonisers of a disturbed area, usually followed by some Cymodoceaceae: Halodule, Cymodocea, Amphibolis, or Syringodium (B̄rouns $19 \hat{9} 8 \bar{f}$, Clarke \& Kirkman 1989). The pattern of species recovery observed in the present experiment is consistent with this sequence of recolonization.

The response to burial also confirms previous suggestions of the importance of vertical growth. Burial has been shown, both in the field (Patriquin 1973, 1975, Marbá et al. 1993, 1994, Marbá \& Duarte 1995) and in laboratory experiments (Marbá \& Duarte 1994) to stimulate the vertical growth of seagrass species with differentiated vertical shoots. Vertical growth increased in response to burial for all species with vertical shoots, except Cymodocea serrulata, which has the fastest vertical growth yet recorded for a seagrass species (Vermaat et al. 1995) and extends its vertical rhizomes into the water column. Hence, burial of $C$. serrulata does not lead to shading of the leaf-producing meristem, which is raised above the sediment, and fails to trigger a growth response similar to that observed in the other species, where vertical growth is a mechanism by which the leaf-producing meristem is raised to the proximity of the sediment surface. The importance of vertical growth as a component of seagrass response to perturbation is best illustrated by the time series of vertical growth of Thalassia hemprichii, which shows (1) an almost immediate increase in response to burial, and (2) a linearity between vertical growth and the extent of burial.

Increased vertical growth was coupled with a substantial (3- to 8-fold) increase in the frequency of branching of vertical shoots. Branching of vertical shoots leads either to the formation of a new vertical shoot, or to the formation of a new horizontal shoot. Both modes of branching were observed in response to burial, although most of the branching corresponded to the division of vertical shoots, which allowed the compensatory response towards increased shoot density observed in some of the species. The increased branching frequency reflects clonal responses to burial, which likely involve the release of apical dominance upon the mortality induced by the disturbance. The increase in branching rate observed in some of the species accounts for the increase in young shoots in the surviving populations of some of the species (e.g. Syringodium isoetifolium). Conversely, changes in age distribution of other species (e.g. Thalassia hemprichii) arose from reduced recruitment and selective mortality of young shoots. It is clear, therefore, that the regulation of the production or survival of young shoots is an important component of the response of the seagrasses to disturbance.

The importance of disturbance as a major factor in dynamic equilibrid has been stiressed in empirical and theoretical arguments (e.g. Sousa 1984, Lewin 1986). It is, for instance, conceivable that the maintenance of mixed meadows such as the one examined here is dependent on the occurrence of disturbance as suggested in the past (Fonseca \& Kenworthy 1987, Clarke \& Kirkman 1989), and that a static situation could lead to the occurrence of monospecific beds, provided that all species use similar resources (cf. Williams 1987. Fourqurean et al. 1995). Moreover, the disturbances needed can range greatly in size, from the $0.5 \mathrm{~m}$ scale of the disturbance associated with the sediment reworking by burrowing shrimps to the $>10^{3} \mathrm{~m}$ scale of disturbances associated with hurricanes and typhoons (Birch \& Birch 1984, Preen et al. 1995). The mosaic of species resulting from these disturbances, as well as the spatial scale of the patchiness derived, must be associated with the scale of the disturbance. The frequency of disturbance is inversely related to its size, so that comparisons of the importance of disturbance must be weighted over sufficiently large spatial and temporal scales. For instance, we observed a density of burrowing shrimp mounds of about $3 \mathrm{~m}^{-2}$, each with an estimated life, based upon observations during the experiment, of a few months. We calculated that the entire meadow is reworked by burrowing shrimps every second year. The resulting frequency of disturbance $\left(0.5 \mathrm{yr}^{-1}\right)$ derived from the activity of burrowing shrimps is much greater than that by typhoons, which swept the area only rarely (Fortes unpubl. data). Hence, the cumulative importance of the small-scale but very frequent sediment reworking by burrowing shrimps cannot be neglected.

The patterns of species loss and recovery observed here support the predictions formulated based on consideration of growth rate and architecture of these species (Vermaat et al. 1997). The patterns of recovery 
observed are dependent, however, on the proximity of survivors immigrating, through clonal growth, into the gap induced by the perturbation. Whether similar patterns of recovery would apply following the largescale loss of seagrasses remains unresolved, and depends on the factors controlling the seed sources over the disturbed area (e.g. morphology of fruit, proximity to reproductive stands, currents). The design of an experiment able to resolve the effects of such a large-scale disturbance is, however, logistically fand possibly legally) cumbersome. The alternative use of 'natural experiments' is, however, flawed by the lack of appropriate controls, which weakens the conclusions derived from them. The results presented here pertain to a disturbance (burrowing shrimps) which is small-scale (in space and time) but which, as stated above, may be more significant to the meadow studied than other, much less frequent large-scale events (tropical storms)

We showed here that sediment disturbances of a scale and magnitude similar to that caused by burrowing shrimps are sufficient to cause major growth and population responses in the Philippine seagrass meadow examined. The fact that the sequence of responses paralleled that postulated on the basis of species growth and architecture suggests that there is hope for the prediction of the nature and time scales of seagrass response to large-scale perturbation.

Acknowledgements. This research was funded by the STD-3 programme of the Commission of the European Union (project TS3"-CT94-0301). We thank Jan Vermaat, Jens Borum, Ole Geertz-Hansen, Lars Kamp-Nielsen, Jack Rengel, and Anjo 'Tita-Mary' Tiquio for assistance in the field and laboratory.

\section{LITERATURE CITED}

Agawin NSR, Duarte CM, Fortes MD (1996) Nutrient limitation of Philippine seagrasses (Cape Bolinao, NW Philippines): in situ experimental evidence. Mar Ecol Prog Ser 138:233-243

Birch WR, Birch M (1984) Succession and pattern of tropical intertidal seagrasses in Cockle Bay, Queensland, Australia: a decade of observations. Aquat Bot 19:343-367

Brouns JJWM (1987a) Growth patterns in some Indo-WestPacific seagrasses. Aquat Bot 28:39-61

Brouns JJWM (1987b) Quantitative and dynamic aspects of a mixed seagrass meadow in Papua New Guinea. Aquat Bot $29: 33-47$

Clarke SM, Kirkman H (1989) Seagrass dynamics. In: Larkum AWD, McComb AJ, Shepherd SA (eds) Biology of seagrasses. Elsevier, Amsterdam, p 304-345

den Hartog C (1971) The dynamic aspect in the ecology of seagrass communities. Thalassia Jugosl 7:101-112

Duarte CM (1991) Allometric scaling of seagrass form and productivity. Mar Ecol Prog Ser 77:289-300

Duarte CM, Marbá N, Agawin NSR, Cebrián J, Enriquez S, Fortes MD, Gallegos ME, Merino M, Olesen B, SandJensen K, Urı JS, Vermaat JE (1994) Reconstruction of sea- grass dynamics: age determinations and associated tools for the seagrass ecologist. Mar Ecol Prog Ser 107:195-209

Eleuterius LN (1987) Seagrass ecology along the coasts of Alabama, Louisiana, and Mississippi. Fla Mar Res Publ 42 $11-24$

Fonseca MS, Kenworthy WJ (1987) Effects of current on photosynthesis and distribution of seagrasses. Aquat Bot 27 . $59-78$

Fonseca MS, Thayer GW, Kenworthy WJ (1987) The use of ecological data in the implementation and management of seagrass restoration. Fla Mar Res Publ 42:175-187

Fortes MD (1994) Seagrass resources of ASEAN. In: Wilkin son CR (ed) Living coastal resources: status and management. Australian Institute of Marine Science, Townsville, p 106-109

Fourqurean JW, Powell GVN, Kenworthy WJ, Zieman JC (1995) The effects of long-term manipulation of nutrient supply on competition between the seagrasses Thalassia testudinum and Halodule wrightii in Florida Bay. Oikos 72:349-358

Kirkman H, Walker DI (1989) Regional studies - Western Australian seagrasses. In: Larkum AWD, McComb AJ, Shepherd SA (eds) Biology of seagrasses. Elsevier, Amsterdam, p $157-181$

Lewin R (1986) In ecology, change brings stability. Science 234:1071-1073

Marbá N, Cebrián J, Enriquez S, Duarte CM (1994) Migration of large-scale subaqueous bedforms measured with seagrasses (Cymodocea nodosa) as tracers. Limnol Oceanogr 39:126-133

Marbá N, Duarte CM (1994) Growth response of the seagrass Cymodocea nodosa to expenmental burial and erosion Mar Ecol Prog Ser 107:307-311

Marba N, Duarte CM (1995) Coupling of seagrass (Cymodocea nodosa) patch dynamics to subaqueous dune migratıon. J Ecol 83:381-389

Marbá N, Gallegos ME, Merino M. Duarte CM (1993) Vertical growth of Thalassia testudinum: seasonal and interannual variability. Aquat Bot 47:1-12

McConnaughay KDM, Bazzaz FA (1991) Is physical space a soil resource? Ecology 72:94-103

Patriquin, DG (1973) Estimation of growth rate, production and age of the marine angiosperm Thalassia testudinum Caribb J Scl 13:111-123

Patriquin DG (1975) Migration of blow-outs in seagrass beds at Barbados and Carriacou, West Indies, and its ecological and ecological and geological implications. Aquat Bot 1:163-189

Poiner IR, Walker DI. Coles RG (1989) Regional studies - Seagrasses of tropical Australia. In: Larkum AWD, McComb AJ, Shepherd SA (eds) Biology of seagrasses. Elsevier, Amsterdam, p 279-303

Preen AR, Lee Long WJ, Coles RG (1995) Flood and cyclone related loss, and partial recovery, of more than $1000 \mathrm{~km}^{2}$ of seagrass in Hervey Bay, Queensland, Australia. Aquat Bot $52: 3-17$

Shepherd SA (1981) The algal and seagrass ecology of Waterloo Bay, South Australia. Aquat Bot 11:305-371

Sousa WP (1984) The role of disturbance in natural commun ties. Annu Rev Ecol Syst 15:353-391

Suchanek TH (1983) Control of seagrass communities and sediment distribution by Callianassa (Crustacea, Thalassinidea) bioturbatıon. J Mar Res 41:281-298

Supanwanid C (1996) Recovery of the seagrass Halophila ovalis after grazing by dugong. In: Kuo J, Phillips RC Walker DI, Kirkman H (eds) Seagrass biology: Proceedings of an International Workshop. University of Western Australia, Perth, p 315-318 
Tilmant JT, Curry RW, Jones R, Szmant A, Zieman JC, Flora M, Robblee MB, Smith D, Snow RW, Wanless H (1994) Hurricane Andrew's effects on marine resources. Bioscience 44:230-237

Turner T (1985) Stability of rocky intertidal surfgrass beds: persistence, preemption and recovery. Ecology 66:83-92

Turner T, Lucas J (1985) Differences and similarities in the community roles of three rocky intertidal surfgrasses. J Exp Mar Biol Ecol 89:175-189

Vermaat JE, Agawin NSR, Duarte CM, Enríquez S, Fortes MD, Marbá N, Uri JS, van Vierssen W (1997) The capacity of seagrasses to survive increased turbidity and siltation: the significance of growth form and light use. Ambio (in press)

Vermaat JE, Agawin NSR, Duarte CM, Fortes MD, Marbá N. Uri JS (1995) Meadow maintenance, growth and produc-

This article was submitted to the editor tivity of a mixed Philippine seagrass bed. Mar Ecol Prog Ser 124:215-225

Ward TJ (1989) The accumulation and effects of metals in seagrass habitats. In: Larkum AWD, McComb AJ, Shepherd SA (eds) Biology of seagrasses. Elsevier, Amsterdam, p $797-820$

Williams SL (1987) Competition between the seagrasses Thalassia testudinum and Syringodium filiforme in a Caribbean lagoon. Mar Ecol Prog Ser 35:91-98

Williams SL (1988) Disturbance and recovery of a deep-water Caribbean seagrass bed. Mar Ecol Prog Ser 42:63-71

Williams SL (1990) Experimental studies of Caribbean seagrass bed development. Ecol Monogr 60:449-469

Ziebis W, Forster S, Huettel M, Jørgensen BB (1996) Complex burrows of the mud shrimp Callianassa truncata and their geochemical impact in the seabed. Nature 382:619-622

Manuscript first received: July 26, 1996

Revised version accepted: December 13, 1996 